\title{
Military Expenditure and Economic Growth Empirical Evidence from Malaysia
}

\author{
Nur Surayya bt Mohd Saudi, Ariffin bin Ismail, Rogis bin Baker, Saizal bin Pinjaman, \\ Aida Nasirah bin Abdullah, Nurhana bin Mohamad Rafiuddin, Amiruddin bin Sulaiman
}

\begin{abstract}
The relationship between military expenditure and economic growth has attract ample interest among economists as well as policy makers. The importance of expanding defence expenditure is substantially to coincide with national security and defence. The purpose of this study is to explore the impact of military expenditure on economic growth in Malaysia. An econometrics time series analysis is employed using ARDL estimates spanning from the year 1979 to 2017. The empirical findings reveal a negative relationship between military expenditure and Gross Domestic Products (GDP). Despite the inverse relationship between defence expenditure and economic growth, Malaysia should not neglect the investment on efficient military expenditure, as it has proven that in some countries, defence expenditure promotes a long run economic growth by promoting more job opportunities, protecting the nation and thus, achieving sustainable development. It is recommended to add more variables in future study that can relate security and defence for the country like numbers of crime, and numbers of migrants and refugees. Conclusively defence and security are the important factors for the country in generating the world and public's confidence and to captivate foreign direct investment. Hence, adequate policy making on military expenditure are utmost important to promote economic growth.
\end{abstract}

Index Terms: Military expenditure; GDP; Security and Defence.

\section{INTRODUCTION}

The relationship between military expenditure and economic growth has attract ample interest among economists as well as policy makers. Military expenditure is a global issue during the end of the Second World War, which provided a chance for developing and developed countries to decrease their military spending. The importance of expanding defence expenditure is substantially to coincide with national security and defence.

Revised Manuscript Received on September 22, 2019.

Nur Surayya bt Mohd Saudi, Faculty of Defence Study and Management, Universiti Pertahanan Nasional Malaysia, Kuala Lumpur, 40400, Malaysia.,nursurayya@upnm.edu.my

Ariffin bin Ismail, Faculty of Defence Study and Management, Universiti Pertahanan Nasional Malaysia, Kuala Lumpur, 40400, Malaysia.

Rogis bin Baker, Faculty of Defence Study and Management, Universiti Pertahanan Nasional Malaysia, Kuala Lumpur, 40400, Malaysia.

Saizal bin Pinjaman, Faculty of Business, Economic and Accounting,Universiti Malaysia Sabah, Kota Kinabalu, 88000, Sabah, Malaysia

Aida Nasirah bin Abdullah, Faculty of Defence Study and Management, Universiti Pertahanan Nasional Malaysia, Kuala Lumpur, 40400, Malaysia.

Nurhana bin Mohamad Rafiuddin, Faculty of Defence Study and Management, Universiti Pertahanan Nasional Malaysia, Kuala Lumpur, 40400, Malaysia.

Amiruddin bin Sulaiman, Faculty of Defence Study and Management, Universiti Pertahanan Nasional Malaysia, Kuala Lumpur, 40400, Malaysia.
Malaysia has had security threats, such as Lahad Datu Incursion in 2012. The country, however, did not increase its military expenditure, with only $1 \%$ increase from $1.43 \%$ to $1.52 \%$ on the percentage of GDP for 2012 to 2013. In addition, the value continuously declined from 2014 to 2017 , [1]. It is thus in question because despite some of the previous literature concluded that military expenditure does not promote economic growth, national defence and security is another important purpose of a country. Various studies have been done to investigate the impact of military expenditure on the countries respectively. For instance, mixed economic findings depict the relationship of military expenditure on economic growth and it is affirmed that defence spending has a negative impact on economic growth. It is also concluded that military expenditure transfers resources from civilian to the defence sector and reduces private savings, hence promoting a negative impact on a country's economic growth. In consequence of the inconsistency of the economic outcome due to military budget allocation, some countries reduced their military budget to focus on possible harmful effects of military expenditure, especially for developing countries. It is argued that military expenditure may lead to imbalance of payment deficit, decrease in economic growth, and as a result, important social and economic expenditure may be crowed out. This paper tries to shed light on the impact of military expenditure on Gross Domestic Product (GDP) by incorporating macroeconomic agents like Real Exchange rate (RER), Consumer price Index (CPI), and population growth.

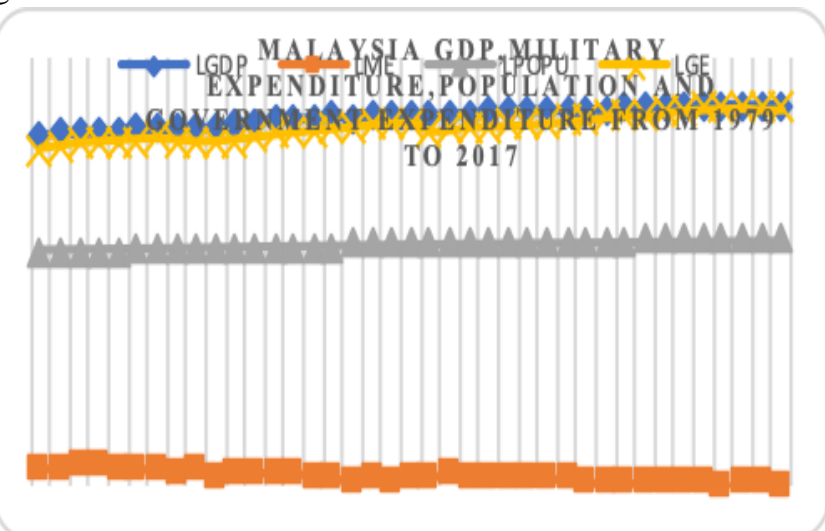

Source: World Development Indicator (WDI)

Published By: Blue Eyes Intelligence Engineering \& Sciences Publication 


\section{LITERATURE REVIEW}

Earlier studies on the impact of military expenditure on economic growth were first initiated by [2] that evidenced military spending may contribute to economic growth by offering public welfare like public infrastructure, education, research and development, that contributes to the betterment for private sector. In addition, the expenditure spent on research and development may possess a positive spill over effect to private production. There are many studies and extended discussions that study the importance of increasing military expenditure and whether military expenditure promotes economic growth for the country. However, most previous studies mainly focus on the causality effect of military expenditure on economic growth. The suggestion is whether the government can increase military spending to boost economic growth or to reduce military spending and allocate more for social welfare. A negative relationship between military expenditure with economic growth can be seen in [3] where an increases in military spending rises the threat in economic growth. While [4] detected United State's productivity growth declined when the expenditure spent on civilian shifted to military. However in another study, [5] suggested that an increase in military expenditure will lead to higher employment, increased profit and greater investment that come from short-run multiplier effect. They added that a huge capital investment spent on military expenditure will boost economic growth. According to [6], military expenditure in developing country helps economic growth by improving social welfares and boosting human capital. [7] claimed that a positive relationship of military expenditure on economic growth occur less in developing countries compared to developed countries. Despite previous literatures that denote negative and positive effects of military expenditure on economic growth, some studies failed to detect the relationship between these two economics determinants. Earlier study by [8] for instance, failed to detect any relationship between military expenditure output and civilian output. However, they claimed that the effect might come from the different estimation econometrics applied in each study. This is also mentioned by [9] that explained that the heterogeneity in findings has often been associated with the use of different samples, different theoretical and econometric specification, and different time lags. Hence the relationship of military expenditure on economic growth could have a positive, negative or an insignificant impact to the country as documented by previous studies on military economic growth nexus literature. This paper firstly fills the research gap by employing econometrics modelling on ARDL estimates as the previous literature emphasised on causality effect in analysing potential relationship. Potential negative or positive relationship with the military expenditure and GDP can be concluded at the end of the study. Secondly, this study incorporates more microeconomic determinants for control variable as it can transform our results into short-run and long-run elasticity, and reduces the sharpness of the time series data so that by the end of the study, it can promote a consistent and reliable estimation [10].

\section{METHODOLOGY}

The model developed for this study incorporates a macroeconomic indicator that can influence the GDP and defence expenditure. All data were extracted from [1]. The general production function of the model is as follows:

$\mathrm{GDP}_{\mathrm{t}}=\mathrm{f}\left(\mathrm{ME}_{\mathrm{t}}, \operatorname{RER}_{\mathrm{t}}, \mathrm{CPI}_{\mathrm{t}}, \mathrm{POPU}_{\mathrm{t}}\right)$

Where

$\mathrm{GDP}_{\mathrm{t}}$, represents Gross Domestic Products

$\mathrm{ME}_{\mathrm{t}}$, represents Military Expenditure

$\mathrm{RER}_{\mathrm{t}}$, represents Real Exchange Rate

$\mathrm{CPI}_{\mathrm{t}}$, represents Consumer Price Index

$\mathrm{POPU}_{\mathrm{t}}$, represents Population

All data were transformed into Log-linear form (LN). The log version of the long-run model is as follows:

$$
\text { LRGDP }_{\mathrm{t}}=\alpha_{0}+\alpha_{1} \text { LME }_{\mathrm{t}-1}+\alpha_{2} \text { LRER }_{\mathrm{t}-1}+\alpha_{3} \text { LCPI }_{\mathrm{t}-1}
$$

$$
+\alpha_{3} \text { LPOPU }_{\mathrm{t}-1}+\mathrm{V}_{\mathrm{t}}
$$

The model includes Real Exchange Rate (RER), Consumer Price Index (CPI) and Population (POPU) as control variables in order to produce a more reliable variable that can influence GDP and military expenditure. We expect RER and CPI to influence the cost of importing weapon from foreign market, which can relate to military expenditure and GDP. We also expect that numbers of POPU to influence GDP and military expenditure as a larger population will increase the government's budget in infrastructure and national defence.

The ARDL model based on Unrestricted Error Correction Model (UECM) is as follows:

$$
\begin{gathered}
\Delta \text { LRGDP }=_{=} \beta_{0}+\alpha_{0} \text { LRGDP }_{\mathrm{t}-1}+\alpha_{0} \text { LME }_{\mathrm{t}-1}+ \\
\alpha_{1} \text { LRER }_{\mathrm{t}-1}+\boldsymbol{\alpha}_{2} \mathrm{LCPI}_{\mathrm{t}_{-1}}+\boldsymbol{\alpha}_{3} \text { LPOPU }_{\mathrm{t}-1}+ \\
\sum \mu_{\mathrm{t}} \Delta \mathrm{LRGDP}_{\mathrm{t}-1}+\sum \mu_{\mathrm{t}} \Delta \mathrm{LME}_{\mathrm{t}-1}+\sum \mu_{\mathrm{t}} \Delta \mathrm{LRER}_{\mathrm{t}-1} \\
+\sum \mu_{\mathrm{t}} \Delta \mathrm{LCPI}_{\mathrm{t}-1}+\boldsymbol{\alpha}_{3} \text { LPOPU }_{\mathrm{t}-1}+\mathrm{V}_{\mathrm{t}}
\end{gathered}
$$

Where $\Delta$ is the difference operator and $\mu$ is a white-noise disturbance term. The null hypothesis of no co-integration on the proposed model is as follows:

$\mathrm{H}_{0}: \theta 0=\theta 1=\theta 2=\theta 3=0$ (there is no long-run relationship).

$\mathrm{H}_{1}: \theta 0 \neq \theta 1 \neq \theta 2 \neq \theta \quad 3 \neq 0$ (there is a long-run relationship).

Given a relatively small sample size in this study of 37 observations, the $\mathrm{F}$ test used for this procedure has a non-standard distribution. Thus, 2 sets of critical values are computed by [11] for a given significance level. Critical values for the $\mathrm{I}(1)$ series are referred to as upper bound critical values, while the critical values for $\mathrm{I}(0)$ series are referred to as the lower bound critical values. If the computed F-statistic exceeds the upper critical bounds value, then the $\mathrm{H}_{0}$ is rejected. We can conclude that there is evidence of a long- run relationship between the variables

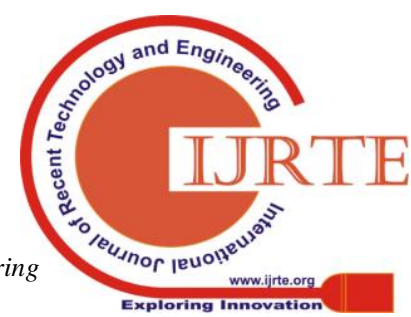


regardless of the order of integration of the variables.

If the F-statistic is below the lower critical bounds value, the $\mathrm{H}_{1}$ is rejected and it implies no co- integration. Lastly, if the F-statistic falls into the bounds, a conclusive inference cannot be made without knowing the order of integration of the underlying repressors.

Table 1: Source of Data

\begin{tabular}{lll}
\hline Variables & Description & Sources \\
\hline GDP & Gross Domestic Products & WDI \\
ME & Military expenditure (\% of GDP) & WDI \\
RER & Real Exchange rate in USD & WDI \\
CPI & Consumer price index (2010 = & WDI \\
& $100)$ & \\
POPU & Total population & WDI
\end{tabular}

Note: WDI stands for World Development Indicator 2019.

\section{EMPIRICAL FINDINGS}

\section{A. Unit-root test}

Before we proceed with the ARDL bounds test, we test for the stationary status of all variables to determine their order of integration. This is to ensure that the variables are not I(2) stationary so as to avoid spurious results. To test the order of integration of variables, we use the standard tests for unit root, namely the Augmented Dickey- Fuller (ADF) and PP (Phillips-Perron). The unit root results show/denote that all variables are stationary at $\mathrm{I}(0)$ and $\mathrm{I}(1)$. Refer to Table 1.

Table 1

\begin{tabular}{lcccc}
\hline Level & \multicolumn{2}{c}{ ADF Unit Root } & \multicolumn{2}{c}{ PP Unit Root } \\
\cline { 2 - 5 } & Intercept & $\begin{array}{c}\text { Intercept } \\
\text { and } \\
\text { Trend }\end{array}$ & Intercept & $\begin{array}{c}\text { Intercept } \\
\text { and } \\
\text { Trend }\end{array}$ \\
\hline LNGDP & -1.8016 & $-1.0133^{*}$ & -0.6732 & $-4.7382^{*}$ \\
LNME & -0.8143 & -1.1000 & -2.876 & -1.987 \\
LNRER & -1.8736 & & -3.876 & -2.200 \\
LNCPI & -1.6655 & -1.9876 & -0.876 & -2.876 \\
LNPOPU & -0.2673 & $-2.394^{*}$ & & \\
& & -1.675 & 0.998 & -1.896 \\
\hline
\end{tabular}

\begin{tabular}{lcccc}
\hline First & \multicolumn{2}{c}{ ADF Unit Root } & \multicolumn{2}{c}{ PP Unit Root } \\
\cline { 2 - 5 } difference & Intercept & $\begin{array}{c}\text { Intercept } \\
\text { and }\end{array}$ & Intercept & $\begin{array}{c}\text { Intercept } \\
\text { and } \\
\text { Trend }\end{array}$ \\
LNGDP & & & Trend \\
\cline { 2 - 5 } & $-5.373 * * *$ & $-4.866 * *$ & $-4.801 * *$ & $-4.9877 *$ \\
& & $*$ & $*$ & $* *$ \\
LNME & $-3.220 * * *$ & $-3.755^{* *}$ & $-3.908 * *$ & $-4.9087 *$ \\
& & & $*$ & $* *$ \\
LNRER & $-2.987 * * *$ & $-5.100 * *$ & $-4.001 * *$ & $-5.001 * *$ \\
& & $*$ & $*$ & $*$ \\
LNCPI & $1.283 * * *$ & $-2.169 * *$ & $-2.113 * *$ & \\
& & $*$ & $*$ & $-2.909 * *$
\end{tabular}

$\begin{array}{lllll}\text { LNPOPU } & -4.000 * * * & -5.589 * * & -4.001 * * & -5.000 * *\end{array}$

Note: $* * *, * *$ and $*$ are significant at the $1 \%, 5 \%$ and $10 \%$ levels, respectively.

\section{B. ARDL Bound Test}

In the step of the ARDL analysis, before testing the existence of a long run relationship among variables, it is important to decide the order of lag of the ARDL. We have selected lags based on Akaike Info Criterion (AIC), and the selected lags are $(1,4,4,2,1)$. The Bound test reported a strong F-value of 7.021 at $1 \%$ significant level. Hence, we rejected the null hypothesis of no co-integration between Gross Domestic Products (GDP) on military expenditure. This result implies that there is a possible long-run or short-run relationship between variables. Hence, we can proceed to test the long-run and short-run relationship.

Table 2

\begin{tabular}{cccc}
\hline Model & $\begin{array}{c}\text { Max } \\
\text { Lag }\end{array}$ & $\begin{array}{c}\text { Lag } \\
\text { order }\end{array}$ & $\begin{array}{c}\mathrm{F} \\
\text { statistic } \\
\text { s }\end{array}$ \\
\hline $\begin{array}{ccc}\text { LNGDP = f(LNME, LNRER, } \\
\text { LNCPI, LNPOPU) }\end{array}$ & $(1,4)$ & $(1,4$, & $7.021^{*}$ \\
& $4,2,1)$ & $* *$ \\
\hline Critical Values for F stat & Lower & Upper \\
& & $\mathrm{I}(0)$ & $(1)$ \\
\hline $10 \%$ & 2.26 & 3.35 \\
$5 \%$ & 2.62 & 3.79 \\
$1 \%$ & 3.41 & 4.68 \\
\hline
\end{tabular}

\section{Diagnostic Test}

Next, diagnostic tests applied to the error correction model indicate that there is no evidence of serial correlation and heteroscedasticity. In addition, normality test implies that the residuals are normally distributed.

Table 3

\begin{tabular}{ccc}
\hline $\begin{array}{c}\text { Serial Correlation } \\
\text { [p-value] }\end{array}$ & $\begin{array}{c}\text { Normality } \\
\text { [p-value] }\end{array}$ & $\begin{array}{c}\text { Heteroscedastic } \\
\text { ity } \\
\text { [p-value] }\end{array}$ \\
\hline 0.9613 & $1.196^{* *}$ & 2.4401 \\
{$[0.1711]$} & {$[0.5947]$} & {$[0.9996]$}
\end{tabular}

Note. $* *$ represents the $5 \%$ significance level.

\section{ARDL Estimations -the short run dynamics and long-run dynamics}

ARDL Estimations - the short run dynamics is the estimation of Error Correction Model (ECM) Estimation results based on Akaiki Info Criterion (AIC), are presented in Table 1. The ECM coefficient has the expected negative $(-0.2990)$ at a strong 5\% significance level. The short-run dynamics of the model show a negative relationship between military expenditure on GDP $-16 \%$ at $5 \%$ significance level. This indicates a $1 \%$ increase on military expenditure reduced $16 \%$ of GDP. The absolute value of the coefficient of error correction term indicates the speed of adjustment to restore equilibrium and the negative sign shows convergence in the short-run dynamic model. The coefficient of $\mathrm{ECM}_{\mathrm{t}-1}$ in this model is 
$-0.2990 * *$ and this means that in each period, about $30 \%$ of shocks can be justified as a long-run trend. The coefficient of $\mathrm{ECM}_{\mathrm{t}-1}$ in our model is negative and highly significant.

Next, the long run relationship displays a stronger negative relationship between military expenditure with GDP at $-1.16,5 \%$ significance level. Thus, in a long-run, an increase of $1 \%$ increase in military expenditure reduces $116 \%$ of GDP. Refer to Table 4.

Table 4

\begin{tabular}{|c|c|c|c|}
\hline \multicolumn{2}{|c|}{ Short run Elasticities } & \multicolumn{2}{|c|}{ Long run Elasticities } \\
\hline Variables & Coefficient & Variables & Coefficient \\
\hline$\Delta \mathrm{LNME}$ & $-0.16^{* *}$ & LNME & $-1.16 * *$ \\
\hline$\triangle$ LNRER & $0.71 * * *$ & LNRER & 2.172 \\
\hline$\Delta \mathrm{LNCPI}_{-1}$ & $-0.002 * * *$ & LNCPI & $-0.09 * *$ \\
\hline$\Delta \mathrm{LNPOP}_{-1}$ & $24.5^{* * *}$ & LNPOPU & $11.9^{* *}$ \\
\hline ECT & $-0.2990 * *$ & $\mathrm{C}$ & $7.765^{* * * *}$ \\
\hline
\end{tabular}

Note: $* * *, * *$ and $*$ are significant at the $1 \%, 5 \%$ and $10 \%$ levels, respectively.

\section{E. Stability Test}

Figure 2 shows the plots of CUSUM and CUSUMSQ statistics are well within the critical bounds, implying that all coefficients in the error correction model are stable. Therefore, this model can be used for policy decision-making purposes, such that the impact of policy changes, considering the explanatory variables of GDP and Military expenditure equation will not cause major distortion in the parameters of this equation.

\section{F. Pairwise Granger Causality Test}

We extend the empirical analysis by testing the causality between military expenditure and GDP. The results in Figure 3 indicate that there is a unidirectional relationship running from GDP to military expenditure. However, there is no feedback effect on military expenditure to GDP. The direction of causality indicates that any policy recommendation on the issue raised should be solved on GDP as it will determine the effect on military expenditure. For this case, Malaysia should reform its policy recommendation on budget allocation for military expenditure in a long-run as higher investment on military expenditure will distort its economic growth.

\section{Stability Test}

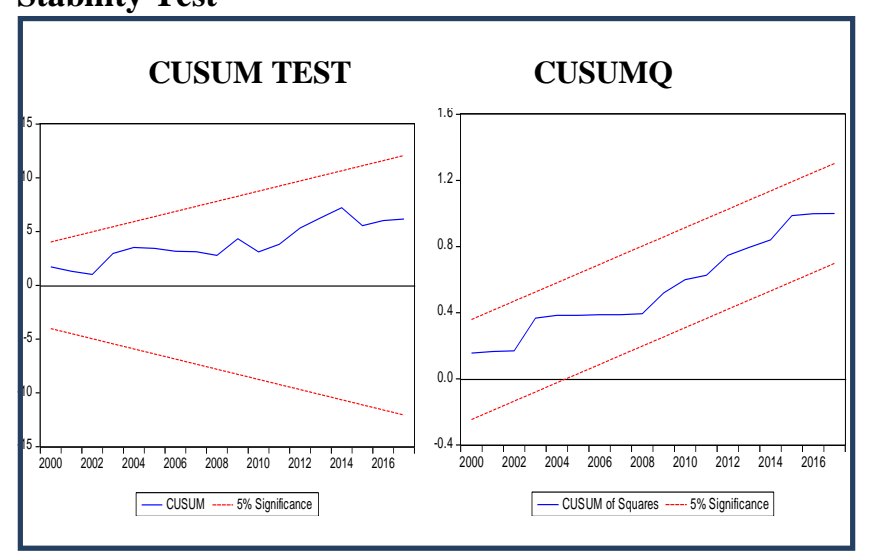

Fig2: Stability Test

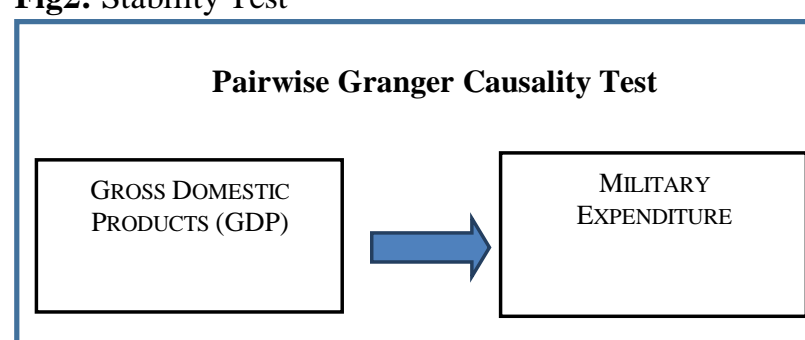

Note: Unidirectional relationship

Fig 3:Pairwise Granger Causality Test

\section{CONCLUSIONS AND POLICY RECOMMENDATIONS}

This paper empirically investigates the long-run, short-run relationship and causality between military expenditure and GDP for Malaysia spanning from 1979 to 2017. The model developed incorporates macroeconomic variables of Real Exchange Rate (RER), Consumer Price Index (CPI) and Population growth (POPU). This paper focuses on military expenditure - GDP nexus and employed a time series data on ARDL estimates. The empirical results suggested that an increasing military expenditure does not help promote economic growth in Malaysia. This finding is in line with [3] and [12] that also proposed the impact of military expenditure on economic growth to be non-significant or negative. In contrary with [13] and [14], that found a positive relationship between military expenditure on economic growth. On the causality analysis, the Granger Causality test revealed a unidirectional relationship running from GDP to military expenditure. Thus, policy recommendation on GDP budget allocation will influence the military expenditure for the country. Despite the inverse relationship between defence expenditure and economic growth, Malaysia should not neglect the investment on efficient military expenditure, as it has proven that in some countries, defence expenditure promotes a long run economic growth by promoting more job opportunities, protecting the nation and thus, achieving sustainable development. It is recommended to add more variables in future study that can relate security and defence for the country like numbers of crime, and numbers of migrants and refugees. Conclusively defence and security are the important factors for the country in generating the world and public's confidence and to captivate foreign direct investment. Hence, adequate policy making on military expenditure are utmost important to promote economic growth.

\section{REFERENCES}

[1] World Development Indicators (2019). World development indicators The World Bank,

Washington, D. C. http:// databank. worldbank. org/ data/ reports. aspx? source $=$ world -

development-indicators (Accessed on 7 January 2018)

[2] Benoit, E. Growth and defense in developing countries. Economic Development and

Cultural Change. 1978;26 (2): 271-80

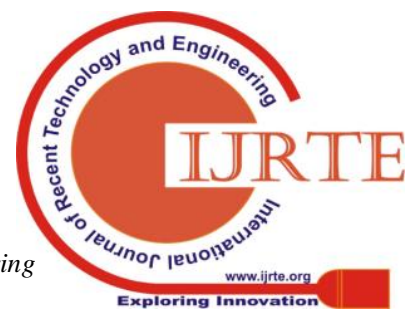


[3] [3] Aizenman, J. and Glick, R. Military expenditure, threats and growth. In NBER Working

Paper. 2003;9618.

[4] Heo, Uk. (2010). The Relationship between Defense Spending and Economic Growth in the

United States. Political Research Quarterly. 2010; 63(4).

[5] Chen, P., Lee, C., \& Chiu, Y. The nexus between defense expenditure and economic growth:

New global evidence. Economic Modelling. 2014;36:474-483. https://doi.org/10.1016/j.econmod.2013.10.019.

[6] Yang, H., Hong, C., Jung, S., \& Lee, J. Arms or butter: The economic effect of an increase

in military expenditure. Journal of Policy Modeling. 2015;37(4):596-615.

https://doi.org/10.1016/j.jpolmod.2015.03.014

[7] Awaworyi, S., \& Yew, S. L. The Effect of Military Expenditure on Growth: An Empirical

Synthesis. Discussion Paper. 2014; 25/14. ISSN:1441-5429.

[8] Biswas, B. and R. Ram.Military expenditures and economic growth in less developed

countries: An augmented model and further evidence. Economic Development and Cultural

Change. 1986;34,(2): 361-72.

[9] Chen P, Lee C, Chiu Y. The nexus between defense expenditure and economic growth :

New global evidence. Econ Model [Internet]. 2014;36:474-83. Available from:

http://dx.doi.org/10.1016/j.econmod.2013.10.019

[10] Shahbaz M, Rahman MM. Foreign Capital Inflows-Growth Nexus and Role of Domestic

Financial Sector: An ARDL Co-integration Approach for Pakistan. J Econ Res [Internet]. 2010;15(January 2010):207-31.Available from: https://www.researchgate.net/publication/228670799

[11] Pesaran MH, Shin Y, Smith RJ. Bounds testing approaches to the analysis of level relationships. J Appl Econom. 2001;16(3):289-326.

[12] Grobar, L. M. \& Porter, R. C. Benoit Revisited: Defence Spending and Economic Growth in LDCs. Journal of Conflict Resolution, 1989;33(2):318-345.

[13] Atesoglu, H.S., Mueller, M.J. Defense Spending and Economic Growth. Defense Economics. 1990;2,:19-27.

[14] Chairil, T., Sinaga, D. S. \& Febrianti, A. I. Relationship between Military Expenditure and Economic Growth in ASEAN: Evidence from Indonesia. Journal of ASEAN Studies.

2013;1(2):106-121.

\section{AUTHOR'S PROFILE}

I am Nur Surayya bt Mohd Saudi from Faculty of Defence Study and Management, Universiti Pertahanan Nasional Malaysia, Kuala Lumpur, 40400, Malaysia. My area of interest finance and management.

My name is Ariffin bin Ismail from Faculty of Defence Study and Management, Universiti Pertahanan Nasional Malaysia, Kuala Lumpur, 40400, Malaysia. My area of interest is sustainability.

I am Rogis bin Baker from Faculty of Defence Study and Management, Universiti Pertahanan Nasional Malaysia, Kuala Lumpur, 40400, Malaysia. My area of interest is sustainability.

My name is Saizal bin Pinjaman from Faculty of Business, Economic and Accounting,Universiti Malaysia Sabah, Kota Kinabalu, 88000, Sabah, Malaysia. My area of interest is accounting and finance.

I am Aida Nasirah bin Abdullah from Faculty of Defence Study and Management, Universiti Pertahanan Nasional Malaysia, Kuala Lumpur, 40400, Malaysia. My area of interest is sustainability.

My name is Nurhana bin Mohamad Rafiuddin currently affiliated with Faculty of Defence Study and Management, Universiti Pertahanan Nasional Malaysia, Kuala Lumpur, 40400, Malaysia. My area of interest is accounting and finance.

I am Amiruddin bin Sulaiman affiliated with the Faculty of Defence Study and Management, Universiti Pertahanan Nasional Malaysia, Kuala Lumpur, 40400, Malaysia. My area of interest is sustainability. 